\section{ZEW}

Zentrum für Europäische Wirtschaftsforschung GmbH

Centre for European Economic Research

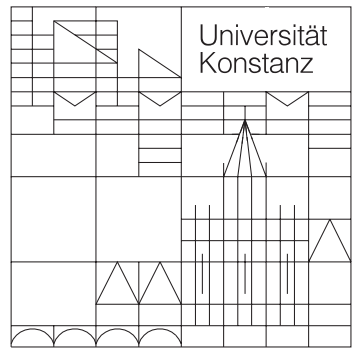

Rechts-, Wirtschafts- und Verwaltungswissenschaftliche Sektion

Fachbereich

Wirtschaftswissenschaften

Diskussionspapiere der DFG-

Forschergruppe (Nr.: 3468269275):

Heterogene Arbeit: Positive und Normative Aspekte der Qualifikationsstruktur der Arbeit

Wolfram Merzyn

Heinrich W. Ursprung

Voter support for privatizing education: Evidence on self-interest and ideology

Juni 2003 
Diskussionspapier der Forschergruppe (Nr.: 3468269275) "Heterogene Arbeit: Positive und Normative Aspekte der Qualifikationsstruktur der Arbeit"

Nr. 03/05, Juni 2003

\title{
Voter support for privatizing education: Evidence on self-interest and ideology
}

\section{Wolfram Merzyn}

Universität Bonn

mail : wolfram.merzyn@wiwi.uni-bonn.de
Heinrich W. Ursprung

\author{
Universität Konstanz \\ Fach D138 \\ 78457 Konstanz \\ Germany \\ mail : heinrich.ursprung@uni-konstanz.de \\ phone : +49-7531-88-2332 \\ fax : $+49-7531-88-3130$
}

\begin{abstract}
:
Economic theory advances various arguments in favor of and against privatizing education. In this paper we investigate the extent to which these arguments influence voters' opinions. We analyze two popular referenda in which some 400,000 voters in two Swiss cantons expressed their opinions on the issue of education vouchers and direct subsidies to private schools. We find that successful attempts to move towards a more privatized education system rest mainly on pure income effects, some other socio-economic determinants, ideological convictions, and possibly the perceived quality of the public schools. Peer-group and tax-burden effects, which play a prominent role in the theoretical literature, do not appear to significantly influence voting behavior.
\end{abstract}

JEL Classification : D72, I28

Keywords : political economy, voter behavior, privatization, education policy, vouchers Download/Reference : http://www.ub.uni-konstanz.de/kops/volltexte/2003/1030/ 


\title{
Voter support for privatizing education:
}

\section{Evidence on self-interest and ideology}

\author{
Wolfram Merzyn \\ Department of Economics \\ University of Bonn \\ Germany
}

\author{
Heinrich W. Ursprung* \\ Department of Economics \\ University of Konstanz \\ Germany
}

June 2003

Keywords: political economy, voter behavior, privatization, education policy, vouchers

JEL Classification: D72, I28

\begin{abstract}
Economic theory advances various arguments in favor of and against privatizing education. In this paper we investigate the extent to which these arguments influence voters' opinions. We analyze two popular referenda in which some 400,000 voters in two Swiss cantons expressed their opinions on the issue of education vouchers and direct subsidies to private schools. We find that successful attempts to move towards a more privatized education system rest mainly on pure income effects, some other socio-economic determinants, ideological convictions, and possibly the perceived quality of the public schools. Peer-group and tax-burden effects, which play a prominent role in the theoretical literature, do not appear to significantly influence voting behavior.
\end{abstract}

We would like to thank the Swiss Federal Statistical Office for kindly providing us with some of the data and Arye Hillman for helpful comments. Valuable research assistance by Heike Henckel and Michael Rauber is also gratefully acknowledged.

*Corresponding author: Box D-138, 78457 Konstanz, tel.: ++49-7531-882332/3713 fax: ++497531-883130; e-mail: Heinrich.Ursprung@uni-konstanz.de 


\section{Introduction}

In almost all developed countries more children attend public or government schools than private schools. At the same time, private schools are usually highly regulated. The literature on the economics of education abounds in arguments that seek to justify these circumstances. Nevertheless, there are also arguments for less public involvement in education, principally because of poor academic achievement in government schools.

In the United States, lamentations about the poor quality of public schools have become an integral part of the economics of education, ${ }^{1}$ as have policy proposals to improve educational quality, ever since the publication of Milton Friedman's by now classical paper on education in 1955. The education economists' preoccupation with school quality reflects the concerns voiced by American parents, educators, members of the business community, and politicians alike. Interestingly, however, it was not so much the low level of academic achievement as such that has been the reason for concern in the United States, but rather the publication of the report $A$ Nation at Risk by the National Commission on Excellence in Education in 1983. This report documented that the United States was inferior to many other countries in educational achievement, which was widely interpreted as threatening the U.S.'s position in business and science. In Germany, to turn to a European example, the lingering uneasiness with the quality of the public education system has only very recently turned into a major issue of the public and political discourse. Just as in the United States the catalyst of the public debate was the release of a cross-country comparison of educational achievement: the PISA 2000 study (Programme for International Student Assessment) published by the OECD in December 2001 indicates that the performance of the 15-year old German students is far below the OECD average in all thee skills

\footnotetext{
${ }^{1}$ See, for example, the recent survey on "Achievement in American schools" by Herbert Walberg (2001).
} 
covered by the study (reading, mathematics, and science). Yardstick competition among national education systems thus appears to be a prime mover in education policy. Many observers are therefore led to conclude that mediocrity in educational achievement can most easily be overcome by introducing more competition in the education sector, for example through free school choice, decentralization, and privatization.

In this paper our focus is on privatization. ${ }^{2}$ Whether the availability of private schools - apart from satisfying basic tenets of liberty - actually does bring about better academic achievements is a controversial empirical issue. ${ }^{3}$ Just as controversial is the argument that private schools are more flexible in responding to specific demands and thus more likely to meet the children's needs and the parents' preferences [cf. Hoxby (1999), Evers and Clapton (2003)]. In any event, these arguments supporting moves towards privatization have not only been challenged on empirical grounds. A theoretical counter argument which is of particular concern stresses the inequalities in educational prospects which sorting in a stratified school system may bring about. If one accepts the propositions that the academic achievement of an individual student depends (among others) on the average ability of his or her immediate peers [for supporting empirical evidence see Zimmer and Toma (2000)] and that children's ability and parents' income are positively correlated with each other, then peer group effects will contribute to differences in academic achievement

\footnotetext{
${ }^{2}$ For a introduction to school choice and decentralization, see Gradstein et al. (2003), chapters 6 and 7.

${ }^{3}$ For direct empirical evidence on differences in academic achievements between private and public schools see, for example, Figlio and Stone (1999), McEwan (2000) and Neal (2002). Indirect evidence relating to the perceived quality difference indicates that in America the marginal household choosing between private and public schooling views a dollar spent on private tuition about $30 \%$ more effective than a tax dollar spent on public education [cf. Cohen-Zada and Justman (2002)]. Apart from the competitive environment private schooling may be better than public schools simply because private schools can better take advantage of family effects on educational achievement than public schools; this is an advantage that is liable to translate into substantial gains in achievement [cf. Hoxby (2001)]. On the competitive pressure exerted by private schools on public schools, see, for example, Couch et al. (1993), Grosskopf et al. (2001), Hoxby (2000), and Woessmann (2003).

${ }^{4}$ A further potential shortcoming of public schooling mentioned in the literature is that public schools do not appear to do well in providing an agreeable social environment for their students. In the Unites States, the safety issue [cf. Coulson (2002)] is particularly topical in this context.
} 
across public and private schools. Moreover, if it is true that weak students benefit more from a strong peer group than good students (as the empirical findings of Summers and Wolfe (1977) suggest), stratification will not only generate inequalities, but also inefficiencies. ${ }^{5}$ Whereas inequalities induced by peer-group effects in a stratified school system are especially opposed by the political left, ${ }^{6}$ another argument in favor of public education has mainly been put forward by the political right: it concerns the role of schools in shaping their students' moral and political values. In contrast to private institutions which are outside the state's control, public schools can reasonably be relied upon to teach their students at least some respect for the country's constitution and thus contribute to long-run political stability. ${ }^{7}$

The often heard claim that private schools provide education in a more efficient manner than public schools mainly relies on the argument that private schools are subject to market forces which alleviate the principal-agent problem between consumers and producers of education [cf. Chubb and Moe (1988)], whereas public schools are monopolies. ${ }^{8}$ The interpretation of the direct empirical evidence on the efficiency issue is, however, controversial since tuition payments or even total expenditures by private schools in many cases do not represent true cost [cf. Levin (1998)]. Moreover, cost differences may also be attributable to the non-random selection of

\footnotetext{
5 The welfare consequences of peer group sorting are analysed, for example, in Benabou (1996) and Epple and Romano (1998).

${ }^{6}$ Notice, however, that the rich may have good reason not to oppose income redistribution with the help of education policies. Dur and Teulings (2001) show, for example, that in a world in which redistribution via the political process is costly, subsidizing education might be a second-best policy.

${ }^{7}$ See, for example, Gradstein and Justman (2003) and Milligan et al. (2003). Lott (1999) shows that ideology also plays an important role in education policy in totalitarian regimes of the left and right variety - albeit for other reasons.

${ }^{8}$ If public schools are subject to Tiebout competition, this can, however, significantly reduce inefficiencies [cf. Hoxby (2000)].
} 
students into private and public schools. ${ }^{9}$ In short, the available empirical evidence on this issue is mixed [cf. Jimenez et al. (1991), Kingdon (1996), McEwan and Carnoy (2000)].

In this paper we do not contribute to the debate on the comparative merits of more or less state or market influence on education. Our objective is thus not to evaluate the size of the different effects attributed to uniform public education and more stratified market-based education systems, but rather to investigate the extent to which these effects are taken into account by the voters in shaping their opinions on education policy. We thus focus our investigation on a purely positive question: we want to identify those theoretical arguments that significantly influence the political process by shaping the voters' preferences. The ultimate objective of this kind of investigation is to evaluate whether proposals that entail a move towards privatization of a public education system have a chance of being implemented. ${ }^{10}$

Surprisingly, the politically all-important issue of voters' preferences and opinions on privatization in education has not been thoroughly investigated so far. To be sure, the political economy of education policy has recently attracted a great deal of attention [see, for example de Fraja (2001), and for an introduction, Gradstein et al. (2003)]. The gainers and losers from the various policy-reform options have thus been identified in theoretical studies and also characterized by rough estimates in calibrated models [cf., for example, Rangazas (1995), Epple and Romano $(1996,1998)$ and Cohen-Zada and Justman (2002)]. Yet very little has been done on revealing the determinants of voter opinions regarding education policies and privatization through empirical research.

\footnotetext{
${ }^{9}$ This may, for example, be the case if students in need of expensive special education are not admitted to private schools. On problems associated with special education, see Cullen and Rivkin (2002).

${ }^{10}$ The disappointing history of referenda on tax support for private schools in the U.S. is summarized in Mendez (1999).
} 
Apart from the very circuitous approach that relates observed policy outcomes to the characteristics of the electorate, three direct routes of empirical investigation are, in principle, available. First, one can elicit the voters' opinions with the help of questionnaire surveys. In the education-policy context, such survey studies have been presented by Belfield (2001) and Brunner and Sonstelie (2002). This method has the advantage of yielding individual data. The analysis of survey data is, however, hampered by the fact that the respondents often do not truthfully reveal their attitudes and personal characteristics (revelation bias), that they need to make hypothetical choices (hypothetical bias) and -- if one is interested in a positive theory of policy determination -- by the fact that political attitudes and vote participation are likely not to be independent, thus resulting in a selection bias (participation bias). ${ }^{11}$ The last two biases can be overcome if individual surveys are carried out shortly after a referendum in so-called "exit polls". The data gleaned from exit polls is, of course, still afflicted with some doubts concerning the truthfulness of the responses, but this method is an effective approach to investigating policy preferences of the active electorate. The major shortcoming of this method is that exit poll analyses usually have to rely on a much smaller sample than normal questionnaire surveys, and the data is collected under a severe time constraint that may compromise accuracy. An interesting exit poll analysis of California Proposition 38 on education vouchers in fall 2000 is to be found in Catterall and Chapleau (2001). The third alternative is to analyze referenda outcomes directly on a precinct basis. This approach is not biased in the above sense; the drawback is that the analysis is conducted on a macro level, which reduces the sample size and generates various aggregation problems. We follow this last route, which is quite novel in the education policy

\footnotetext{
${ }^{11}$ That the participation bias may give rise to severely false estimates in forecasting the outcomes of referenda is documented in de Melo et al. (2002).
} 
context and complements the other available approaches to identifying the determinants of voter preferences. ${ }^{12}$

Our empirical analysis covers two referenda on rather timid privatization schemes held in two Swiss cantons. In these referenda some 400,000 voters expressed their opinion. Even though we cannot rely on individual data, we do have a rather rich data set at our disposal. This data set encompasses the results of the two referenda at the community level, which translates into 165 and 241 observations, respectively.

The paper is organized as follows. In section 2 we present the institutional background of the two referenda. The main arguments in favor and against privatizing education are transformed into testable hypotheses in section 3. The regression results are presented in section 4 . Section 5 concludes.

\section{The institutional setting}

The Swiss political system, at the federal as well as at the state (cantonal) level, is characterized by semi-direct democracy. In a semi-direct democracy, just as in pure representative democracies, most legislation is initiated by the executive and then modified, amended and enacted by a parliamentary decision. The Swiss system is special in allowing for popular referenda; laws that have already passed Parliament are presented for acceptance to the voters at large. These referenda are either mandatory if the constitution calls for a referendum in prespecified cases, or they are facultative, meaning that a certain number of voters can demand that

\footnotetext{
${ }^{12}$ A very informative analysis of precinct returns on California's Propositon 174 on education vouchers is to be found in Brunner et al. (2001). This analysis focuses, however, primarily on the housing price premium to explain the returns. The Catterall and Chapleau (2001) study, which also analyzes referendum returns in California (Proposition 38), uses rather imprecise demographic measures and a somewhat suspect econometric implementation (see our section 3). Some simple correlation results of referendum results are presented in Mendez (1999).
} 
the referendum take place; in some few cases Parliament effectuates a popular referendum even without any constitutional requirement to do so. A last kind of referendum, called an initiative, is initiated by a prescribed minimum number of voters who demand that a piece of legislation, which they propose themselves, is directly put to a popular vote, thereby sidestepping Parliament. In these cases the executive and legislative bodies can either simply inform the voters about their reasoned evaluation of the popular initiative (usually they are against the proposed piece of legislation) or they can propose alternative legislation, which is then, together with the popular initiative, also voted upon in the popular referendum.

The two popular referenda analyzed in this study both concern pieces of legislation that entail (rather timid) moves toward a more market-based or more privatized education system. Both referenda concern cantonal laws, since education in Switzerland is the policy responsibility of the cantons. The first referendum took place in the year 2001 in the canton of Ticino, the Italian speaking part of Switzerland, and belongs to the fourth variety discussed above. The proposed piece of legislation came about via a popular initiative and concerned providing vouchers to parents who send children to private schools. The cantonal Parliament objected to this proposal, mainly because a majority of the Ticino MPs felt that the original proposal was not affordable given the canton's public spending capabilities. Parliament therefore formulated an alternative, cheaper, voucher scheme that was adopted against the opposition of the members on the left of the political spectrum. Both proposals were rejected by voters after an intense public debate that was reported by the media throughout Switzerland: the popular initiative was rejected by $74.1 \%$ of the voters, and the Parliament's counter-proposal was rejected by $72.3 \%$ of voters. ${ }^{13}$

\footnotetext{
${ }^{13}$ The results of both proposals are highly correlated with each other. We therefore restrict our analysis to the popular initiative.
} 
The second referendum was in the canton of Zurich in 1999. In this case no mandatory referendum was required and nor did the voters demand one; it was rather a parliamentary majority that thought it prudent to ask the voters to consent to a new law regulating high schools. ${ }^{14}$ This law introduced various means of granting public middle schools more autonomy from the ministry of education, such as conceding the parents a free choice of schools, and delegating hiring and dismissal of teachers to the school management, thereby abolishing the civil-servant status of public school teachers. These measures were politically rather uncontroversial. The political debate centered mainly on one paragraph of the law, which allows the government to subsidize private high schools up to one third of the cost of public schooling. The two major parties on the right and on the left of the political spectrum, the Social Democratic Party (SPS) and the People's Party (SVP), spearheaded the opposition against this provision. To avoid a referendum organized by these two parties, the Parliament of the canton of Zurich decided to put the law directly to a popular referendum, in order to gain time and to outmaneuver the opposition. The opponents' attempt to let the voters decide separately on the controversial paragraph on private school subsidization was thwarted by a parliamentary majority. The ensuing public debate leading up to the referendum was, as a consequence, dominated by the issue of subsidies to private high schools. Even though, technically speaking, the referendum was on the entirety of the new high school law, in the eyes of the voters the overriding issue was whether private schools should or should not be subsidized. The outcome of the referendum was that $60 \%$ of voters supported the new law. This is significantly less than the comfortable majorities that supported new laws regulating the organization of the public university $(77 \%$, March 1998) and the public middle schools (82\%, September 1997). The smaller majority (and

\footnotetext{
14 The U.S. high school corresponds, more or less, to what is called "middle school" in Switzerland. In order not to confuse the reader, we will use the U.S. term throughout. In any case, we refer to schools attended by children aged
} 
the somewhat higher than past voter participation) was certainly due to the emotional campaign unleashed by the People's Party.

The most fundamental objective of our empirical study is to investigate the extent to which voters followed ideological predispositions or based their positions on arguments stressed by education economics. Both referenda are well suited for this purpose since the ideological dimension of the proposed policy changes was very much part of both campaigns and both referenda were on proposals that result in less government involvement in education.

A little over 400,000 voters participated in the two referenda, 85,363 in Ticino (voter participation rate: $43.1 \%$ ) and 317,802 in Zurich (voter participation rate: $44.9 \%$ ). Our data set consists of the approval rates and various socio-economic indicators for each ballot district. Ballot districts in Switzerland basically coincide with the municipalities; we could thus use data from 241 municipalities in the canton of Ticino and 165 in the canton of Zurich. ${ }^{15}$

\section{Estimation technique}

We use a standard binary choice model (cf. Pindyck and Rubinfeld, 1998, ch. 11) that relates the probability that an individual voter will vote "yes" in a referendum to a vector of observable socio-economic variables. ${ }^{16}$ The randomization is due to the fact that some characteristics influencing a voter's education policy preferences are not observable. We use the following logit representation, which assumes that the probability $\mathrm{P}_{\mathrm{i}}$ of voter $\mathrm{i}$ voting yes can be described by a

\footnotetext{
15-18 and to the law regulating these schools (Mittelschulgesetz, dated 13 June 1999).

${ }^{15}$ In both cantons, six municipalities had to be neglected in the empirical analysis because of lack of data.

16 This approach has been used in many studies of popular referenda. See, for example, Schulze and Ursprung (2000).
} 
cumulative logistic probability function of his or her observable socio-economic characteristics $\mathrm{X}_{\mathrm{i}}$ :

$$
P_{i}=\frac{1}{1+e^{-\left(a+b X_{i}\right)}}
$$

The logistic specification results in a "log-odds" function that is linear in the exogenous variables $\mathrm{X}_{\mathrm{i}}$ :

$$
\log \frac{P_{i}}{1-P_{i}}=a+b X_{i}
$$

Since we do not have individual data, we approximate the probability $P_{i}$ by the fraction $r_{j} / s_{j}$ of "yes" votes in ballot district $\mathrm{j}$, where $\mathrm{r}_{\mathrm{j}}$ denotes the number of voters voting "yes" in district $\mathrm{j}$ and $\mathrm{s}_{\mathrm{j}}$ denotes the number of voters participating in the referendum in district $\mathrm{j} .{ }^{17} \mathrm{We}$ thus arrive at the regression equation

$$
\log \frac{r_{j} / s_{j}}{1-r_{j} / s_{j}}=a+b X_{j}+u_{j} .
$$

For independent observations the error term $u_{j}$ is asymptotically normally distributed with mean zero and variance $\operatorname{Var}\left(u_{j}\right)=\frac{s_{j} / r_{j}}{s_{j}-r_{j}}$ so that the above regression equation needs to be divided by $\sqrt{\operatorname{Var}\left(u_{j}\right)}$ in order to make the regression homoscedastic.

\footnotetext{
${ }^{17}$ Implicitly, this aggregation presupposes a homogenous electorate in each district. As shown by McFadden and Reid (1975) we may, as a consequence, well underestimate individual elesaticities.
} 


\section{Testable hypotheses}

The presumption in favor of political economy

Our basic hypothesis is that voter preferences with respect to privatizing education are at least codetermined by economic factors. We thus conjecture that in the referenda individual voters make their decisions by taking into account whether they would derive personal economic benefits or losses from the proposed policy reforms. We thus propose our

\section{Basic hypothesis (economics matters):}

Economic factors identified by theoretical investigations of the political economy of education policy substantially influence voter behavior.

In the following we elaborate on the political-economic determinants that are believed to influence voting behavior and show how the respective effects can be estimated in regression analyses of the two referenda. Before doing so, we should, however, like to emphasize that our basic hypothesis by no means implies that non-economic determinants have no influence on voting behavior. We rather acknowledge that voting behavior is also subject to influences that have little to do with individual welfare considerations. We summarize these influences as ideological biases of the voters and explicitly introduce them in our last hypothesis.

\section{Income-related determinants}

Theoretical investigations of voter preferences with respect to public versus private provision of education emphasize the role of income. Three income-related aspects dominate the discussion: 
pure income effects, tax-burden effects and peer-group effects. We shall discuss these effects in turn and begin with the pure income effect.

Education appears to be a normal good, i.e. demand for education increases with increasing income. Well-to-do voters are thus more likely to vote for public financial support of high quality private schools, since this will either benefit them directly if they already send their children to private school, or will allow them to send their children to private school if public support in the form of subsidies or vouchers makes private schooling sufficiently inexpensive.

The tax-burden effect is more ambiguous. On the one hand, in the case of voucher financing (the subsidy case is analogous), all children who attend a private school will obtain a voucher. The direct effect of introducing a voucher scheme thus increases the tax-burden. If, however, the voucher induces some parents to switch their children from public to private schooling, total public expenditures for schooling will begin to decrease since the value of the voucher is less than the cost of public schooling. A second indirect effect may make public schools more costefficient because public schools now face more formidable competition. The direct negative tax burden effect can, of course, be larger or smaller than the anticipated indirect positive effects through attendance-induced and competition-induced cost reductions. It is an empirical matter to determine whether the direct effect is greater or less than the indirect effects. In any event, these tax burden effects are felt by all voters, but given proportional or even progressive income taxation, the largest benefits or losses would accrue to the rich. ${ }^{18}$

Perceived peer group effects are, at least to some extent, income-related because it is often believed that academic proficiency is correlated with income. This belief may be based on the presumption that children of richer parents receive a higher quality home education, or that

\footnotetext{
${ }^{18}$ Notice, that public high schools in Switzerland are financed via (cantonal) income taxation.
} 
genetic influences are at work. Whatever the basis for the assumption, if peer-group effects are noticeable, an increase in private school attendance dilutes the peer-group advantage of the private schools, which, if the effect is sufficiently strong, will lead rich parents oppose any proposal that is likely to increase private school attendance of inferior peers. ${ }^{19}$

To illustrate the three income-related effects, consider a school system with only two types of schools: private and public. The following Cobb-Douglas function specifies voter (or parent) i's utility as a function of disposable income and quality of education: ${ }^{20}$

(1) $\quad U^{i}= \begin{cases}U_{p u b}^{i}=(1-t) y_{i} \theta_{p u b}^{\gamma}, & \text { if child is sent to public school } \\ U_{p r}^{i}=\left((1-t) y_{i}-p+v\right) q \theta_{p r}^{\gamma}, & \text { if child is sent to private school }\end{cases}$

where $\theta$ denotes the average ability of the school-specific peers, $\mathrm{p}$ private school tuition, $\mathrm{v}$ the voucher or subsidy level, ${ }^{21}$ and $\mathrm{q}>1$ the quality premium of private schooling. We envisage a proportional income tax. Income is assumed to be uniformly distributed over the unit interval and the income tax rate $\mathrm{t}$ is determined via the budget constraint of the government:

$$
\hat{y} c+(1-\hat{y}) v=t \bar{y} \Rightarrow t=\frac{v+(c-v) \hat{y}}{\bar{y}},
$$

where $\mathrm{c}>\mathrm{v}$ denotes the cost of public schooling, $\bar{y}=1 / 2$ average income, and $\hat{y} \in(0,1)$ the critical income level at which parents are indifferent between private and public schooling, i.e. parents whose income exceeds $\hat{y}$ send their children to private school. Assume furthermore that the child's ability $b_{i}$ is perfectly correlated with his or her parent's income: $b_{i}=\alpha+\beta y_{i}$. We then have

\footnotetext{
${ }^{19}$ If family income and student ability is not correlated, but private schools can discriminate in their tuition and admittance policies, similar but more complex patterns of gainers and loosers from policy reform result [cf. Epple and Romano (1998)].

${ }^{20}$ This specification, which presupposes that each voter is the parent of one child, is quite standard in the literature.
} 


$$
\theta_{p u b}=\alpha+\beta \hat{y} / 2 \text { and } \theta_{p r}=\alpha+\beta(\hat{y}+1) / 2
$$

Substituting (3), and (2) into the equation $\mathrm{U}_{\mathrm{pr}}=\mathrm{U}_{\text {pub }}$ yields

$$
\{[1-2 v-2(c-v) \hat{y}] \hat{y}-p+v\} q\left(\alpha+\beta \frac{1+\hat{y}}{2}\right)^{\gamma}-[1-2 v-2(c-v) \hat{y}] \hat{y}\left(\alpha+\beta \frac{\hat{y}}{2}\right)^{\gamma}=0
$$

This equation thus describes the critical income $\hat{y}$ as an implicit function of the model's parameters: $\hat{y}=\hat{y}(v, \gamma ; c, p, q, \alpha, \beta)$. Substitution of the critical value $\hat{y}$ in the utility function (1) then immediately yields voter i's utility as a function of his or her income $y_{i}$, the policy variable $\mathrm{v}$, and the parameter $\gamma$ measuring the strength of the peer group effect. $\mathrm{U}(\mathrm{y}, \gamma, \mathrm{v}=0)$ implies no voucher for private schools. Comparing $\mathrm{U}(\mathrm{y}, \gamma, \mathrm{v}=0)$ with $\mathrm{U}(\mathrm{y}, \gamma, \bar{v}>0)$ we can then identify the gainers and losers from a proposed voucher $\bar{v}$ as compared to the status quo $v=0$.

In order to isolate the three income-related effects identified above, consider first a scenario in which peer-group effects are absent $(\gamma=0)$ and the tax-burden effect does not play any role $(t=0)$; i.e. the expressions in the square brackets in equation (4) are set equal to one. Under these circumstances the critical income turns out to be $\hat{y}=\frac{q}{q-1}(p-v)$ and the voters' utility functions have the following appearance:

(1a) $U^{i}=\left\{\begin{array}{c}U_{p u b}^{i}=y_{i}, \text { if } y<\hat{y} \\ U_{p r}^{i}=\left(y_{i}-p+v\right) q, \text { if } y \geq \hat{y}\end{array}\right.$

The graphs of this utility function for $\mathrm{v}_{0}=0$ and $\mathrm{v}_{1}>0$ are depicted in Figure 1, which shows that the pure income effect generates a weak political cleavage between the income groups: the poorer voters (those whose income is below $\left.\hat{y}\left(v_{1}\right)\right)$ are indifferent, whereas the richer voters favor the

For a similar specification see, for example, Epple and Romano (1998). 
proposed voucher scheme. The figure also shows that some middle class voters or parents, namely those whose income is between $\hat{y}\left(v_{0}\right)$ and $\hat{y}\left(v_{1}\right)$, will switch their children from public to private schooling if the policy change is implemented.

In a second step we incorporate the tax-burden effect but still assume that no peer-group effects are present $(\gamma=0)$. Implicit differentiation of equation (4) yields

$$
\frac{d \hat{y}}{d v}=-\frac{-2(q-1)\left(\hat{y}-\hat{y}^{2}\right)+q}{(q-1)\langle 1-2 v-4(c-v) \hat{y}\rangle}<0
$$

for $\mathrm{c}<1 / 4 .^{22}$ That is, voucher financing of private schools will again make some middle income earners switch their children from public to private schooling. Moreover, notice that in the utility function

$$
U^{i}=\left\{\begin{array}{c}
U_{p u b}^{i}=[1-2 v-2(c-v) \hat{y}] y_{i}, \text { if } y<\hat{y} \\
U_{p r}^{i}=\left([1-2 v-2(c-v) \hat{y}] y_{i}-p+v\right) q, \text { if } y<\hat{y}
\end{array}\right.
$$

the term $(1-\mathrm{t})=[1-2 v-2(c-v) \hat{y}]$ can increase or decrease as $\mathrm{v}$ increases, depending on the size of the term $\frac{\partial \hat{y}}{\partial v}$ that measures the policy-impact on the fraction of parents who switch from public to private schooling. Since the first term of $\frac{\partial[\cdot]}{\partial v}=-2(1-\hat{y})-2(c-v) \frac{\partial \hat{y}}{\partial v}$ is negative, an increase in $\mathrm{v}$ will decrease $(1-\mathrm{t})=[$.$] and thus increase the tax rate \mathrm{t}$ if the introduction of the policy reform has no effect on the fraction of children sent to private school, i.e. if the second, positive, term is negligible. If the policy change does not significantly alter private school attendance, the increase in $\mathrm{v}$ will give rise to an increase in the tax rate $\mathrm{t}$. Notice, also, that an increase of $\mathrm{v}$

\footnotetext{
${ }^{21}$ Subsidies are supposed to be passed on to the parents by way of a reduction in tuition.

${ }^{22}$ The numerator is positive since the term $y-y^{2}$ does not exceed $1 / 4$. The denominator is minimized for $y=1$ but still
} 
reduces the intercept of $\mathrm{U}_{\mathrm{pr}}\left(\mathrm{y}_{\mathrm{i}}\right)$. The policy reform can thus generate, via the tax-burden effect, a more complex political cleavage, which is portrayed in Figure 2. In this figure we assume that the tax-burden effect is negative. ${ }^{23}$ Figure 2 shows that poor voters lose, whereas the middle class gains from the policy reform. The rich may gain or lose depending on the size of the tax-burden effect as compared to the transfer received.

Finally, we turn to the peer-group effect and set $\gamma=1$. In doing so we again suppress the taxburden effect ( $\mathrm{t}=0$ ). Differentiation of the implicit function (4) then yields

$$
\frac{d \hat{y}}{d v}=-\frac{q\left(\alpha+\beta \frac{1+\hat{y}}{2}\right)}{q\left(\alpha+\beta \frac{1+\hat{y}}{2}\right)+\frac{\beta}{2} q(\hat{y}-p+v)-(\alpha+\beta \hat{y})}<0,
$$

implying again that the envisaged policy reform will give rise to more parents sending their children to private school. As can be seen from the utility function

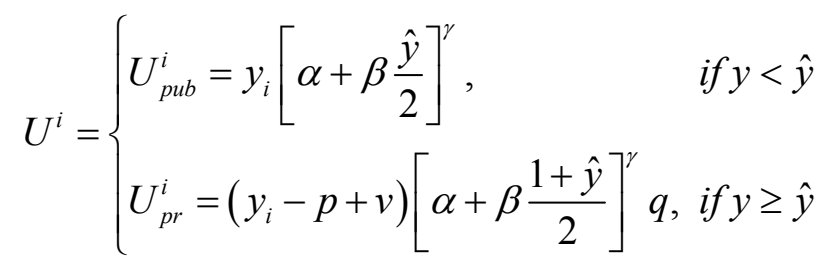

an increase in $\mathrm{v}$ reduces the slope of $U_{\text {pub }}$ and $U_{\text {pr }}$ and decreases the intercept of $U_{\text {pr }}$. As a result we may end up with a political cleavage that closely resembles the one brought about by the taxburden effect depicted in Figure 2. Again the poor will be on the losing side and so are the rich if the peer-group effect as measured by $\gamma$ is sufficiently strong.

positive if $\mathrm{c}<1 / 4$.

${ }^{23}$ If the tax-burden effect were positive, all voters would gain from increasing $\mathrm{v}$. 
The simple model presented above illustrates the presumption that a coalition of the "ends against the middle" may result from the tax-burden and/or the peer-group effect of privatizing education [a similar political cleavage emerges in the endogenous education policy model presented by Epple and Romano (1996)]. If the political cleavage really separated the middle class from the rich and the poor -- the middle class reaping the politically contestable rents just as "Director's Law" predicts [see Stigler (1970)] -- we would observe a hump-shaped approval function in terms of income. If the combined impact of the tax-burden and the peer-group effects is not sufficiently strong to make the approval function bend down, i.e. if the pure income effect dominates the other two effects, we are faced with the run-of- the-mill hypothesis that the individual acceptance of proposals towards privatizing education varies positively with income. This gives rise to our

\section{Hypothesis 1 (pure income effect):}

Voter support for proposed policy change (voucher proposal in Ticino, subsidy scheme in Zurich) increases with the average district income. The only exception to this rule may be high-income districts.

Our second income-related hypothesis acknowledges Director's Law:

\section{Hypothesis 2 (tax-burden cum peer-group effect):}

For high-income districts, voter support varies negatively with the average district income. 
So far we have argued with a counterfactual model, assuming that each household or parent has exactly one child. The number of children however varies substantially across households, which changes the picture to some extent. For households (voters) with many children, private schooling is much more expensive than for parents who have only one child. Also, through the tax system, families with fewer children subsidize the public education of children of families with more children. We therefore conjecture that, ceteris paribus, voters with many children are less in favor of privatizing education than voters with fewer children. ${ }^{24}$ This consideration gives rise to

\section{Hypothesis 3 (family structure):}

Voter support for the proposed policy reforms decreases with the share of children below the age of 15 in the district population.

We now turn to determinants of political preferences, which are still voter-specific but transcend the blunt impact of personal income.

\section{Socio-economic determinants}

An important class of economic determinants of the voters' stances on privatizing education concerns heterogeneous preferences. Parents who have an especially high regard for education are more likely to approve subsidizing high quality private education. In our model one could, portray such a preference bias by assigning a high individual value to the parameter $\mathrm{q}$ that

\footnotetext{
${ }^{24}$ For households who do not have any children in education and for whom dynastic considerations do not play any
} 
measures the perceived advantage of private schooling. Since we have no data on "taste for education," we attempt to capture preferences for high-quality education by using the parents' educational achievement. This gives rise to

\section{Hypothesis 4 (parents'education):}

Voter support varies positively with the district-specific share of people with a vocational training.

In the case of the referendum in the canton of Ticino an additional consideration deserves attention. The existing private schools in this canton mostly subscribe to the classical catholic education program. It is obvious that voters endorsing the traditional catholic code of belief are more likely to send their children to a catholic school and are therefore, ceteris paribus, more likely to approve of the proposed voucher scheme. In order to measure the extent to which voters adhere to the traditional catholic code of belief, we use the outcome of a referendum on the issue of abortion. Assuming that a vote in favor of a strict prohibition of abortion is strongly correlated with a belief in the traditional catholic creeds, we arrive at

\section{Hypothesis 5 (religion)}

In the referendum in the canton of Ticino, voter support for the proposed voucher scheme varies positively with voter support for a strict prohibition of abortion.

role, only the tax-burden effects is at work [cf. Poterba (1997) for some related empirical evidence]. 


\section{Community-specific determinants}

The third and last class of economic determinants refers to community-specific factors. First, geography is likely to have an influence on voting behavior since the existing private (high) schools are all located in centers of agglomeration. ${ }^{25}$ Even if the proposed policy reforms would eventually lead new private schools to enter the market, probably no voter would expect this to happen in the near future and not to the extent that geographic considerations would no longer matter. We thus propose

\section{Hypothesis 6: (geography)}

The larger the distance of a municipality to the canton's center of agglomeration, the lower is voter support.

Another consideration likely to influence voters in a municipality is the quality of the local public schools. In our model the parameter q measures the perceived quality advantage of the private schools. This quality advantage increases as the quality of the public schools decreases. ${ }^{26}$ Since performance indicators of local public schools have up to now not been an issue in the political discourse in Switzerland, we use as a proxy variable the share of foreigners among children aged below fifteen living in a given municipality, speculating that the extensive debate on the (unfavorable) influence of immigration on the quality of education sensitized the voters' concern for the performance of public schools. This variable, of course, may not only pick up the resource

\footnotetext{
${ }^{25}$ In the canton of Zurich all existing private high schools are located in the metropolitan area of Zurich. In the canton of Ticino the existing private schools are located in the biggest cities of that canton, namely in Bellinzona, Locarno and Lugano.

${ }^{26}$ To be sure, local public schools are primary and middle schools. These schools do not directly compete with the private high schools that were the subject of the referendum in Zurich. Nevertheless, we are quite confident in assuming that the exposure to a poorly performing local public school would induce the voters to adopt a more
} 
drain associated with the schooling of incompletely assimilated immigrant children but also a perceived (negative) peer-group effect. We thus propose

\section{Hypothesis 7: (performance of public schools)}

The greater the proportion of foreigners among the children in a municipality, the larger is voter support for the proposed policy change.

\section{Ideological or non-economic determinants}

We now, finally, turn to the non-economic determinants of voting behavior. Whereas the economic determinants are related to personal costs and benefits associated with the proposed policy reform, non-economic determinants refer to a voter's political ideology. The main political ideology that opposes privatization is socialism. The social democrats in Switzerland are one of the four large political parties that, on the level of the federation, make up the grand coalition that has characterized the Swiss political landscape since the Second World War. Their strong concern for distributional equality makes them natural opponents to any policy change that is likely to generate substantial differences in educational quality or achievements because they fear that differences in human capital accumulation will eventually translate into income differences. ${ }^{27}$ Measuring the prevalence of the socialist ideology by the vote share of the Social Democratic Party in the 1999 election to the cantonal parliament, we arrive at

\footnotetext{
favorable attitude towards private schooling.

${ }^{27}$ A further argument might be that in a mixed education system the rich may have an incentive to reduce the budget for public schools. We did not analyze this kind of endogenous policy response which is investigated in Epple and Romano (1996) and informally discussed in Romer (2002).
} 


\section{Hypothesis 8: (socialism)}

The larger the vote share of the Social Democratic Party in the election to the cantonal parliament, the smaller will be the voter support for the proposed policy change.

Interestingly, it is not only the socialists who oppose moves towards privatizing education; people endorsing a nationalist ideology also tend to defend the traditional public education system. Nationalists favor uniform public education because they tend to believe that such a system has a melting-pot feature that helps to inculcate traditional state-preserving notions and values. The main large party in Switzerland that subscribes to convictions that at times have a nationalistic touch is the People's Party. In the canton of Zurich the People's Party is especially strong and assertive, and since it recommended that voters oppose the proposed high-school law, we propose

\section{Hypothesis 9: (nationalism)}

The larger the vote share of the People's Party in the general election in the canton of Zurich, the smaller will be voter support for the proposed subsidization scheme.

We do not formulate an analogous hypothesis for the referendum held in the canton of Ticino because the People's Party is politically insignificant in that canton. ${ }^{28}$

\footnotetext{
${ }^{28}$ The vote share of the People's Party in 1999 amounted to $29 \%$ in Zurich and to less than 3\% in Ticino. There is a rather sizable right-wing protest party in Ticino, the so-called Lega Ticinese, which, however, does not have a nationalistic touch but rather a heavy coating of local patriotism akin to the Italian Lega Nord.
} 


\section{Results}

The estimation results for the Ticino referendum are summarized in Table 1 and the results for the Zurich referendum in Table 2.

In both regressions income has a positive and highly significant influence on the approval rate. This is perfectly consistent with our first hypothesis, which postulates a positive pure income effect. The squared-income variable is also significant, and the negative sign indicates that voter support is a concave function of income. Both estimated functions peak at a value almost at the upper end of the income distribution; in the canton of Ticino four out of the 241 municipalities have an average income exceeding the critical income at which income begins to have a negative effect on voter support, and in the canton of Zurich three out of 165 municipalities lie in the range of the downward sloping part of the function. This shows that the combined effect of tax-burden and peer-group considerations as postulated in our Hypothesis 2 is at best of very minor political importance.

When the number of children is included as an additional explaining variable in the regressions in order to correct for family size - the respective results are presented in the second columns of the two tables -- the pure income effect survives, whereas in the Ticino regression the tax-burden cum peer-group effect loses significance. Our reservations with respect to Hypothesis 2 are thus corroborated. With regard to family structure, we find that this variable indeed has a significant influence of voter support; the larger the average number of children per family, the smaller is voter support. Our third hypothesis thus clearly stands up to empirical scrutiny.

Turning to the variables that capture the voters' social background, we include in both regressions a variable that captures voters' level of education. This variable measures the share of 
the adult population who has undergone some kind of vocational training. ${ }^{29}$ According to Hypothesis 4, this variable should have a positive effect on voter support. To test Hypothesis 5, we also include in the Ticino regression a variable that measures the extent to which the voters adhere to the traditional catholic code of belief. Since we speculate that strict Catholics will have been in favor of a strict law prohibiting abortion, we base our variable on the outcome of a referendum on the issue of abortion conducted in $1985 .{ }^{30}$ The respective regression results are shown in the third columns of the two tables. Hypothesis 5 passes the empirical test with flying colors, whereas Hypothesis 4 does not as well. In the Zurich referendum the level of education has the predicted positive effect on voter support and is significant at the $1 \%$ level. In the Ticino referendum, however, the level of education does not appear to have had an influence on voting behavior. We conjecture that in this referendum the parochial outlook of the established private schools may have dominated the high-quality education angle underlying our hypothesis.

Economic determinants that are common to all voters in a given municipality are introduced in the next step. Here we test the hypotheses that maintain that the opportunity cost of private schooling influences voting behavior. If private schooling implies that students need to commute to the closest center of agglomeration, the value of subsidizing private schooling decreases with increasing distance to these centers of agglomeration. The results shown in the fourth columns of the two tables do not provide strong support for our Hypothesis 6. Even though the respective coefficients have in both regressions the correct sign, the impact is far from being statistically significant. Hypothesis 7 , which maintains that a high foreign population in a municipality is likely to decrease the quality of the local public schools and thus will make private schooling

\footnotetext{
${ }^{29}$ Including the share of the adult population with an academic degree causes problems because this share is rather small and highly correlated with income.

${ }^{30}$ A similar referendum conducted in 2002 yields analogous but somewhat less sharp results because the 2002 referendum was much less controversial.
} 
more attractive, fares better. In the case of the Zurich referendum the variable FOREIGNERS has the correct sign and is significant at the $1 \%$ level. In the Ticino referendum, however, the FOREIGNERS variable is not significant. We speculate that this asymmetry is due to the fact that the composition of the foreign residents with respect to origin is quite different in Zurich and Ticino.

So far we have only included determinants of "egoistic" voting behavior in our regressions. According to our last two hypotheses we however expect that ideological determinants also influence voters' decisions. For both referenda we advanced the hypothesis that voters who embrace socialist convictions are less likely to vote for a more privatized school system This is our Hypothesis 8. Moreover, we advanced the hypothesis that also a nationalist ideology will also make a voter less likely to be in favor of a "denationalized" school system. For lack of a good proxy-variable in the canton of Ticino, we can test this last Hypothesis 9 only for the referendum conducted in the canton of Zurich, which is the stronghold of the nationalist wing of the People's Party of Switzerland. The regression results are presented in the fifth columns of the two tables. Nationalistic ideologies appear to have a strongly significant negative effect on a voter's willingness to accept a more privatized school system. Hypothesis 9 thus seems to be confirmed by the empirical evidence. The only doubt that one could entertain in this context is that the proponents of the People's Party who campaigned against the subsidization of private schools did so by stressing not so much the melting-pot argument but rather the fear that such a policy would be likely to increase the government's budget. It is possible that the well-off supporters of the People's Party were more easily convinced by this argument than other voters. Interestingly, socialist convictions do not appear to have influenced the outcome of the Zurich referendum. Perhaps this is due to the Social Democratic Party's reluctance to be seen united in the campaign with the rather odd bedfellow to the right of the political spectrum. Only in the canton of Ticino, 
where these ulterior political considerations were absent, can we identify a clear negative influence of socialist ideological convictions on the outcome of the referendum to confirm our Hypothesis 8 .

In both regressions that include all explanatory variables (cf. columns 5 in Tables 1 and 2) the CHILDREN variable is not significant anymore. The main reason for this loss of significance lies in the CHILDREN variable's relatively strong correlation with the CATHOLIC (in the case of Ticino) and FOREIGNER (in the case of Zurich) variables. In order to illustrate this point we present in column 6 of the two tables the regression results with the respective "troublemakers" omitted. In both cases the CHILDREN variable easily regains significance at a fairly high level. Of course, omitting important explaining variables from the regression equation may well lead to severe biases, so it would be prudent not to conclude from these results that the CHILDREN variable necessarily does have a significant influence on voting behavior. However, what the results $d o$ demonstrate is that the CHILDREN variable's relatively low significance in columns 5 is (at least partly) due to difficulties in disentangling the causal effects of the above mentioned regressors and should not be interpreted as there being no relationship between the share of children and share of yes votes in a given municipality. As a first step towards assessing the strength of the identified effects on voting behavior we computed the respective elasticities at the mean $\bar{X}$ of all the exogenous variables: ${ }^{31}$

$$
\varepsilon_{P, x_{k}}(\bar{X})=\left.\frac{\partial P}{\partial x_{k}} \frac{\bar{x}_{k}}{P}\right|_{X=\bar{X}}=\left[1-F\left(\bar{X}^{\prime} \beta\right)\right] \beta_{k} \bar{x}_{k} .
$$

\footnotetext{
${ }^{31}$ Our computations are based on the estimation results in columns 5 of Table 1 and 2 . We do not report elasticities for the variables which are not significant nor for the dummy variable DISTANCE. As for the INCOME variable it does not make sense to consider changes in the linear and quadratic terms separately. Therefore, we have only computed the cumulative effect.
} 
The results are shown in Table 3. A 10\% increase in income in the canton of Ticino will, for example, increase the approval rate by $2.1 \%$. While elasticities have the virtue of being easy to interpret, they do not take differences in variation between the explaining variables into account. Whereas, for example, the ratio of the $90^{\text {th }}$ and the $10^{\text {th }}$ percentile for the CHILDREN variable is only 1.7, the corresponding figure for INCOME lies much higher at 5.9. The elasticities in Table 3 thus tend to understate the importance of INCOME relative to CHILDREN. In order to correct this bias we multiplied all elasticities by the ratio of the respective variable's standard deviation and mean in Table 4. The results clearly demonstrate that INCOME is the most important determinant of voting behavior. In Ticino religious convictions also play a major role with ideological convictions coming in third. The influence of all other variables seems to be rather modest.

\section{Conclusions}

We have presented an empirical study of voting on policies that add elements of privatization to education in two Swiss cantons. Our study identifies the most important determinants of voter preferences on education. This kind of information is of fundamental importance for designing privatization schemes that can be expected to have political support.

The results show that voter preferences are substantially influenced by the economic determinants emphasized in the theoretical literature on the economics of education. Voters are thus demonstrated to be self-interested and rational, that is, they are more likely to support privatization schemes in education if they anticipate benefits, and vice versa if they do not expect to gain. The empirical evidence thereby supports our basic hypothesis and corroborates the results obtained from studies using questionnaire surveys [as for example Belfield (2001)]. A 
second important conclusion from our investigation is that political cleavage in education policy does not appear to be characterized by the often-invoked presumption of an "ends against the middle" coalition. We rather concur with Cohen-Zada and Justman (2002), whose computational model indicates that the issue of financing education aligns poorer voters against richer ones, with the consequence that the median voter remains decisive.

The reason why the rich support privatization of education through voucher and subsidy schemes is that they do not expect that the rather timid policy changes that we analyzed in this paper will bring about an increase of their tax burden; and nor do they believe that an increase in the number of students attending private schools would expose their own children to a worse peer-group environment. Another interpretation would maintain that the rich favor privatization in the education system because of the opportunity to reduce government spending on public schools, which their children would then not attend.

Measuring peer-group effects is a complicated endeavor, as is measuring the influence of perceived peer-group effects on preferences for privatizing education. If peer-quality and income are correlated -- as we assumed -- then peer-group and income effects are difficult to disentangle. The above result, which firmly puts the rich voters on the side of the supporters of the proposed policy changes, indicates, however, that peer-group considerations did not play an important role in the referenda. This evaluation is confirmed by the minor effect of the proportion of foreign children on voter behavior; the effect is significant, but the respective elasticity is rather small.

Our finding that perceived public school quality does not vary all that much with the proportion of foreigners does not imply that quality considerations do not influence voters' preferences. On the contrary, we strongly believe that the perceived quality of the public school is an important determinant in shaping voter preferences and voting behavior. We were, however, not in a 
position to use quality differences between public schools across ballot districts as an explanatory variable because such data is not (yet) available in Switzerland. This effect therefore shows up in the constant term of our regressions. Investigating the quality of public schooling is an interesting and important subject for future research.

It is perhaps not surprising that, apart from socio-economic determinants, ideological convictions also have an important role in a policy debate as controversial as education policy. We therefore believe that the advocates of greater privatization in education have a significant public relations task in convincing the electorate of the merits of this position. As far as the design of specific privatization proposals is concerned, the dominant role of the income effect identified in our study indicates that it is paramount that the policy reforms make private education available to a large part of the electorate; this can be achieved via appropriately designed income-dependent financial support schemes. Just as important for the successful implementation of privatization proposals, albeit more difficult to accomplish, may be to convey, especially to poorer voters, a firm commitment to high academic standards in the part of the education system that will remain public. 


\section{References}

Belfield, C., 2001. Political preferences and the privatization of education: Evidence from the UK. National Center for the Study of Privatization in Education, Occasional Paper No. 18.

Benabou, R., 1996. Heterogeneity, stratification, and growth: Macroeconomic implications of community structure and social finance. American Economic Review 86, 584-609.

Brunner, E., Sonstelie, J., Thayer, M., 2001. Capitalization and the voucher: An analysis of precinct returns from California's Proposition 174. Journal of Urban Economics 50, 517-536.

Brunner, E., Sonstelie J., 2002. Homeowners, property values, and the political economy of the school voucher. National Center for the Study of Privatization in Education, Occasional Paper No. 56.

Catterall, J., R. Chapleau, R., 2001. Voting on vouchers: A socio-political analysis of California Proposition 38, Fall 2000. National Center for the Study of Privatization in Education, Occasional Paper No. 42.

Chubb, J., T. Moe, T., 1988. Politics, Markets, and the Organization of Schools. American Political Science Review 82, 1065-1087.

Cohen-Zada, D., Justman, M., 2002. The political economy of school choice: Linking Theory and Evidence. National Center for the Study of Privatization in Education, Occasional Paper No. 57.

Couch, J., Shugart II, W., Williams, A., 1993. Private school enrollment and public school Performance. Public Choice 76, 301-312.

Coulson, A., 2002. Delivering education. In:, Lazear, E. Education in the $21^{\text {st }}$ century. Hoover Institution, Books Online, pp. 105-145.

Cullen, J. and Rivkin, S., 2003. The role of special education in school choice. In C. Hoxby, The economics of school choice. Chicago, Chicago University Press.

De Fraja, G., 2001. Education policies: Equity, efficiency and voting equilibrium. Economic Journal 111, C104-C119.

Dur, R., Teulings, C., 2001. Education and efficient redistribution. Tinbergen Institute Discussion Paper.

Epple, D., Romano, R., 1996. Ends against the middle: Determining public service provision when there are private alternatives. Journal of Public Economics 62, 297-325. 
Epple, D., Romano, R., 1998. Competition between private and public schools, vouchers, and peer group effects, American Economic Review 88, 33-62.

Evers, W., Clopton, P., 2003. The curricular smorgasbord. In: Peterson, P. Our schools and our future... Are we still at risk? Hoover Institution, Online Books, pp. 239-279.

Friedman, M., 1955. The role of government in education. In Solow, R. Economics and the public interest. Rutgers University Press.

Figlio, D., Stone, J., 1999. Are private schools really better? Research in Labor Economics $18,115-140$.

Gradstein, M., Justman, M., Meier, V., 2003. Education: A political economy perspective. (Where ?) forthcoming

Gradstein, M., Justman, M., 2003. Education, Social Cohesion, and Economic Growth. American Economic Review, forthcoming.

Grosskopf, S., Hayes, K., Taylor, L., Weber, W., 2001. On the determinants of school district efficiency: Competition and monitoring. Journal of Urban Economics 49, 453-78.

Hoxby, C., 1999. When parents can choose, what do they choose? In: Peterson, P., Mayer, S. Earning and learning: How schools matter. Brookings Institution Press, Washington, D.C., pp. 281-316.

Hoxby, C., 2000. Does Competition among public schools benefit students and taxpayers? American Economic Review 90, 1209-1238.

Hoxby, C., 2001. If families matter most, where do schools come in? In: Lazear, E. A primer on America's schools. Hoover Institution, Books Online, pp. 89-125.

Jimenez, M., Lockheed, M., Paqueo, V., 1991. The relative efficiency of private and public schools in developing countries, World Bank Research Observer 6, 205-218.

Kingdon, G., 1996. The quality and efficiency of private and public education: A case study for urban India. Oxford Bulletin of Economics and Statistics 58, 57-82.

Levin, H., 1998. Educational vouchers: Effectiveness, choice, and costs. Journal of Policy Analysis and Management 17, 373-392.

Lott, J., 1999. Public schooling, indoctrination, and totalitarianism. Journal of Political Economy 107, 127-157.

McEwan, P., 2000. Comparing the effectiveness of public and private schools: Review of evidence and interpretations. National Center for the Study of Privatization in Education, Occasional Paper No. 3. 
McEwan, P., Carnoy, M., 2000. The effectiveness and efficiency of private schools in Chile's voucher system. Educational Evaluation and Policy Analysis 22, 213-239.

McFadden, D., Reid, F., 1975. Aggregate travel demand forecasting from disaggregated behavioral models. Transportation Research Record 534, 24-37.

de Melo, J., Miguet, F., Müller T., 2002. The political economy of EU Enlargement: Lessons from Switzerland. CEPR discussion paper No. 3449.

Mendez, A., 1999. Voters versus vouchers: An analysis of referendum data. Phi Delta Kappa 81, September, 76-78.

Neal, D., 2002. How vouchers could change the market for education. Journal of Economic Perspectives 16, 25-44.

Pindyck, R., Rubinfeld, D., 1998. Econometric models and economic forecast. McGraw-Hill, New York.

Poterba, J., 1997. Demographic structure and the political economy of Public education. Journal of Policy Analysis and Management 16, 48-66.

Rangazas, P., 1995. Vouchers and voting: An initial estimate based on the median voter model. Public Choice 82, 261-279.

Romer, P., 2002. Redistributional Consequences of Educational Reform. In Lazear, E. A primer on America's schools. Hoover Institution, Books Online, 89-125.

Schulze, G., Ursprung, H., 2000. La donna e mobile - or is she? Voter preferences and public support for the performing arts. Public Choice 102, 131-149.

Stigler, G., 1970. Director's law of public income distribution, Journal of Law and Economics 13, 1-10.

Summers, A., Wolfe, B., 1977. Do schools make a difference? American Economic Review 67, 639-652.

Walberg, H.,2001. Achievement in American schools. In Moe, T. A primer on America's schools Hoover Institution, Books online, 43-67.

Woessmann, L., 2003. Schooling resources, educational institutions, and student performance: The international evidence. Oxford Bulletin of Economics and Statistics, forthcoming

Zimmer, R., Toma, R., 2000. Peer effects in private and public schools across countries. Journal of Policy Analysis and Management 19, 75-92. 
Table 1: regression results of the Ticino referendum (endogenous variable: APPROVAL)

\begin{tabular}{|c|c|c|c|c|c|c|}
\hline Variable & $(1)$ & (2) & (3) & (4) & (5) & (6) \\
\hline CONSTANT & $\begin{array}{l}-13.51 \\
(-18.79)\end{array}$ & $\begin{array}{l}-9.75 \\
(-5.82)\end{array}$ & $\begin{array}{l}-16.82 \\
(-7.27)\end{array}$ & $\begin{array}{l}-15.85 \\
(-4.98)\end{array}$ & $\begin{array}{l}-11.95 \\
(-3.61)\end{array}$ & $\begin{array}{l}-2.76 \\
(-0.96)\end{array}$ \\
\hline INCOME & $\begin{array}{l}0.0053^{* *} \\
(4.22)\end{array}$ & $\begin{array}{l}0.0044 * * \\
((3.45)\end{array}$ & $\begin{array}{l}0.0066^{* *} \\
(5.19)\end{array}$ & $\begin{array}{l}0.0058^{* *} \\
(4.25)\end{array}$ & $\begin{array}{l}0.0053 * * \\
(3.94)\end{array}$ & $\begin{array}{l}0.0041^{* *} \\
(2.93)\end{array}$ \\
\hline $\begin{array}{l}\text { INCOME } \\
\text { SQUARED }\end{array}$ & $\begin{array}{l}-1.01 \mathrm{E}-6^{*} \\
(-2.16)\end{array}$ & $\begin{array}{l}-7.63 \mathrm{E}-7 \\
(-1.62)\end{array}$ & $\begin{array}{l}1.19 \mathrm{E}-6^{* *} \\
(-2.63)\end{array}$ & $\begin{array}{l}-9.61 \mathrm{E}-7^{*} \\
(-2.03)\end{array}$ & $\begin{array}{l}-9.00 \mathrm{E}-7^{+} \\
(-1.94)\end{array}$ & $\begin{array}{l}-7.71 \mathrm{E}-7 \\
(-1.59)\end{array}$ \\
\hline CHILDREN & & $\begin{array}{l}-0.22 * \\
(-2.49)\end{array}$ & $\begin{array}{l}-0.15^{+} \\
(-1.68)\end{array}$ & $\begin{array}{l}-0.14 \\
(-1.54)\end{array}$ & $\begin{array}{l}-0.14 \\
(-1.56)\end{array}$ & $\begin{array}{l}-0.21^{*} \\
(-2.31)\end{array}$ \\
\hline EDUCATION & & & $\begin{array}{l}-0.008 \\
(-0.14)\end{array}$ & $\begin{array}{l}-0.027 \\
(-0.37)\end{array}$ & $\begin{array}{l}-0.023 \\
(-0.41)\end{array}$ & $\begin{array}{l}-0.061 \\
(-1.02)\end{array}$ \\
\hline CATHOLIC & & & $\begin{array}{l}0.12 * * \\
(6.19)\end{array}$ & $\begin{array}{l}0.13 * * \\
(6.12)\end{array}$ & $\begin{array}{l}0.11 * * \\
(4.98)\end{array}$ & \\
\hline DISTANCE & & & & $\begin{array}{l}-0.46 \\
(-1.50)\end{array}$ & $\begin{array}{l}-0.53^{*} \\
(-1.76)\end{array}$ & $\begin{array}{l}-0.422 \\
(-1.35)\end{array}$ \\
\hline FOREIGNERS & & & & $\begin{array}{l}-9.84 \mathrm{E}-4 \\
(-0.06)\end{array}$ & $\begin{array}{l}-0.0086 \\
(-0.52)\end{array}$ & $\begin{array}{l}-0.033^{*} \\
(-2.02)\end{array}$ \\
\hline $\begin{array}{l}\text { SOCIAL } \\
\text { DEMOCRATS }\end{array}$ & & & & & $\begin{array}{l}-0.144 * * \\
(-3.46)\end{array}$ & $\begin{array}{l}-0.205 * * \\
(-4.90)\end{array}$ \\
\hline $\mathrm{R}^{2}$ (unadjusted) & 0,156 & 0,178 & 0,295 & 0,302 & 0,336 & 0,264 \\
\hline F-statistic & 21,98 & 17,06 & 19,66 & 14,38 & 14,65 & 11,96 \\
\hline
\end{tabular}

+ significance at the $10 \%$ level

* significance at the $5 \%$ level

** significance at the $1 \%$ level 
Table 2: regression results of the Zurich referendum (endogenous variable: APPROVAL)

\begin{tabular}{|c|c|c|c|c|c|c|}
\hline Variable & (1) & (2) & (3) & (4) & $(5)$ & (6) \\
\hline constant & $\begin{array}{l}0.071 \\
(0.10)\end{array}$ & $\begin{array}{l}10.91 \\
(7.60)\end{array}$ & $\begin{array}{l}4.31 \\
(1.50)\end{array}$ & $\begin{array}{l}-0.658 \\
(-0.21)\end{array}$ & $\begin{array}{l}-2.265 \\
(-0.64)\end{array}$ & $\begin{array}{l}1.61 \\
(0.49)\end{array}$ \\
\hline INCOME & $\begin{array}{l}0.0050 * * \\
(5.02)\end{array}$ & $\begin{array}{l}0.0033^{* *} \\
(3.89)\end{array}$ & $\begin{array}{l}0.0028^{* * *} \\
(3.15)\end{array}$ & $\begin{array}{l}0.0043^{* *} \\
(4.52) \\
\end{array}$ & $\begin{array}{l}0.0039 * * \\
(4.22)\end{array}$ & $\begin{array}{l}0.0027 * * \\
(3.26)\end{array}$ \\
\hline $\begin{array}{l}\text { INCOME } \\
\text { SQUARED }\end{array}$ & $\begin{array}{l}-7.34 \mathrm{E}-7 * * \\
(-3.03)\end{array}$ & $\begin{array}{l}-5.11 \mathrm{E}-7^{*} \\
(-2.50)\end{array}$ & $\begin{array}{l}-3.12 \mathrm{E}-7 \\
(-1.46)\end{array}$ & $\begin{array}{l}-6.03 \mathrm{E}-7 * * \\
(-2.70)\end{array}$ & $\begin{array}{l}-4.60 \mathrm{E}-7 * \\
(-2.16)\end{array}$ & $\begin{array}{l}-2.54 \mathrm{E}-7 \\
(-1.25)\end{array}$ \\
\hline CHILDREN & & $\begin{array}{l}-0.557 * * \\
(-8.33)\end{array}$ & $\begin{array}{l}-0.487 * * \\
(-6.88)\end{array}$ & $\begin{array}{l}-0.255^{* *} \\
(-2.64)\end{array}$ & $\begin{array}{l}-0.132 \\
(-1.39)\end{array}$ & $\begin{array}{l}-0.246^{* *} \\
(-2.79)\end{array}$ \\
\hline EDUCATION & & & $\begin{array}{l}0.138^{* *} \\
(2.64)\end{array}$ & $\begin{array}{l}0.108^{*} \\
(2.09)\end{array}$ & $\begin{array}{l}0.165^{* *} \\
(3.26)\end{array}$ & $\begin{array}{l}0.180 * * \\
(3.51)\end{array}$ \\
\hline DISTANCE & & & & $\begin{array}{l}-0.0098 \\
(-0.71)\end{array}$ & $\begin{array}{l}0.0082 \\
(0.59)\end{array}$ & $\begin{array}{l}-0.0011 \\
(-0.08)\end{array}$ \\
\hline FOREIGNERS & & & & $\begin{array}{l}0.058^{* *} \\
(3.15)\end{array}$ & $\begin{array}{l}0.048^{* *} \\
(2.75)\end{array}$ & \\
\hline $\begin{array}{l}\text { SOCIAL } \\
\text { DEMOCRATS }\end{array}$ & & & & & $\begin{array}{l}-1.22 \mathrm{E}-4 \\
(-0.003)\end{array}$ & $\begin{array}{l}-0.0028 \\
(0.073)\end{array}$ \\
\hline $\begin{array}{l}\text { PEOPLES' } \\
\text { PARTY }\end{array}$ & & & & & $\begin{array}{l}-0.0917 * * \\
(-3.82)\end{array}$ & $\begin{array}{l}-0.099 * * \\
(-4.08)\end{array}$ \\
\hline $\mathrm{R}^{2}$ (unadjusted) & 0,347 & 0,543 & 0,562 & 0,595 & 0,644 & 0,626 \\
\hline F-statistic & 43,183 & 63,82 & 51,27 & 38,63 & 35,28 & 37,46 \\
\hline
\end{tabular}

+ significance at the $10 \%$ level

* significance at the $5 \%$ level

** significance at the $1 \%$ level 
Table 3: Elasticities for the probability to approve with respect to the exogenous variables, at the joint mean

\begin{tabular}{|c|c|c|c|c|c|c|}
\hline & INCOME & CHILDREN & EDUCATION & FOREIGNERS & CATHOLIC & IDEOLOGY \\
\hline Ticino & 0,211 & $-0,154$ & -- & -- & 0,347 & $\begin{array}{c}-0,175 \\
(\text { left })\end{array}$ \\
\hline Zurich & 0,128 & $-0,102$ & 0,286 & 0,032 & -- & $\begin{array}{c}-0,149 \\
\text { (right) }\end{array}$ \\
\hline
\end{tabular}

Table 4: Elasticities adjusted by the ratio of the respective variable's standard deviation and mean.

\begin{tabular}{|c|c|c|c|c|c|c|}
\hline & INCOME & CHILDREN & EDUCATION & FOREIGNERS & CATHOLIC & IDEOLOGY \\
\hline Ticino & 0,156 & $-0,039$ & -- & -- & 0,125 & $-0,068$ \\
\hline Zurich & 0,077 & $-0,015$ & 0,026 & 0,022 & -- & $-0,042$ \\
\hline
\end{tabular}




\section{Appendix A: Data sources}

All data employed refer either to the 165 included municipalities in the Canton of Zurich (ZH) [we did not include the City of Zurich itself], or to the 241 municipalities in the Canton of Ticino (TI). The municipalities are identical with the ballot districts.

\begin{tabular}{|l|l|l|l|}
\hline Variable & Canton & Explanation & Source \\
\hline INCOME & ZH, TI & $\begin{array}{l}\text { average per-capita federal income tax revenue } \\
1995 / 1996\end{array}$ & $\begin{array}{l}\text { Swiss Federal Tax } \\
\text { Administration } \\
\text { (www.estv.admin.ch) }\end{array}$ \\
\hline FOREIGNERS & ZH, TI & $\begin{array}{l}\text { share of foreign residents among the resident } \\
\text { population aged below 15 }\end{array}$ & Population Census 2000 \\
\hline EDUCATION & ZH, TI & $\begin{array}{l}\text { share of the resident population with a vocational } \\
\text { training as their highest educational qualification }\end{array}$ & Population Census 1990 32 \\
\hline CHILDREN & ZH, TI & Share of the resident population up to 15 years & Population Census 2000 \\
\hline DISTANCE & TI & $\begin{array}{l}\text { Distance to closest private school, dummy } \\
\text { variable with range 0-3 }\end{array}$ & own computation \\
\hline DISTANCE & ZH & $\begin{array}{l}\text { Estimated travel time to the Zurich main railway } \\
\text { station in minutes }\end{array}$ & $\begin{array}{l}\text { Swiss Federal Railway, } \\
\text { SBB-online } \\
\text { http://www.rail.ch/index_e.htm }\end{array}$ \\
\hline CATHOLIC & TI & $\begin{array}{l}\text { Share of voters who advocated a total ban of } \\
\text { abortions in a 1985 federal referendum }\end{array}$ & $\begin{array}{l}\text { Ufficio di statisitica, Cantone } \\
\text { Ticino } \\
\text { http://www.ti.ch/DFE/USTAT/ }\end{array}$ \\
\hline $\begin{array}{l}\text { SOCIAL } \\
\text { DEMOCRATS }\end{array}$ & TI & $\begin{array}{l}\text { Vote share of the social democratic party, } \\
\text { general election to the Ticino parliament, 1999 }\end{array}$ & $\begin{array}{l}\text { Ufficio di statisitica, Cantone } \\
\text { Ticino } \\
\text { http://www.ti.ch/DFE/USTAT/ }\end{array}$ \\
\hline $\begin{array}{l}\text { SOCIAL } \\
\text { DEMOCRATS }\end{array}$ & ZH & $\begin{array}{l}\text { Vote share of the social democratic party, } \\
\text { general election to the Zurich parliament, 1999 } \\
\text { Züristisches Amt des Kantons } \\
\text { http://www.statistik.zh.ch/ }\end{array}$ \\
\hline PEOPLE'S PARTY & Z & $\begin{array}{l}\text { Vote share of the People's Party (SVP), general } \\
\text { election to the Zurich parliament, 1999 }\end{array}$ & $\begin{array}{l}\text { statistisches Amt des Kantons } \\
\text { Zürich } \\
\text { http://www.statistik.zh.ch/ }\end{array}$ \\
\hline
\end{tabular}

\footnotetext{
${ }^{32}$ As for the EDUCATION variable the results of the Population Census 2000 are not available yet. Given that (in a country like Switzerland) this variable can be expected not to change much within a decade we do not consider the use of the old data to be highly problematic.
} 


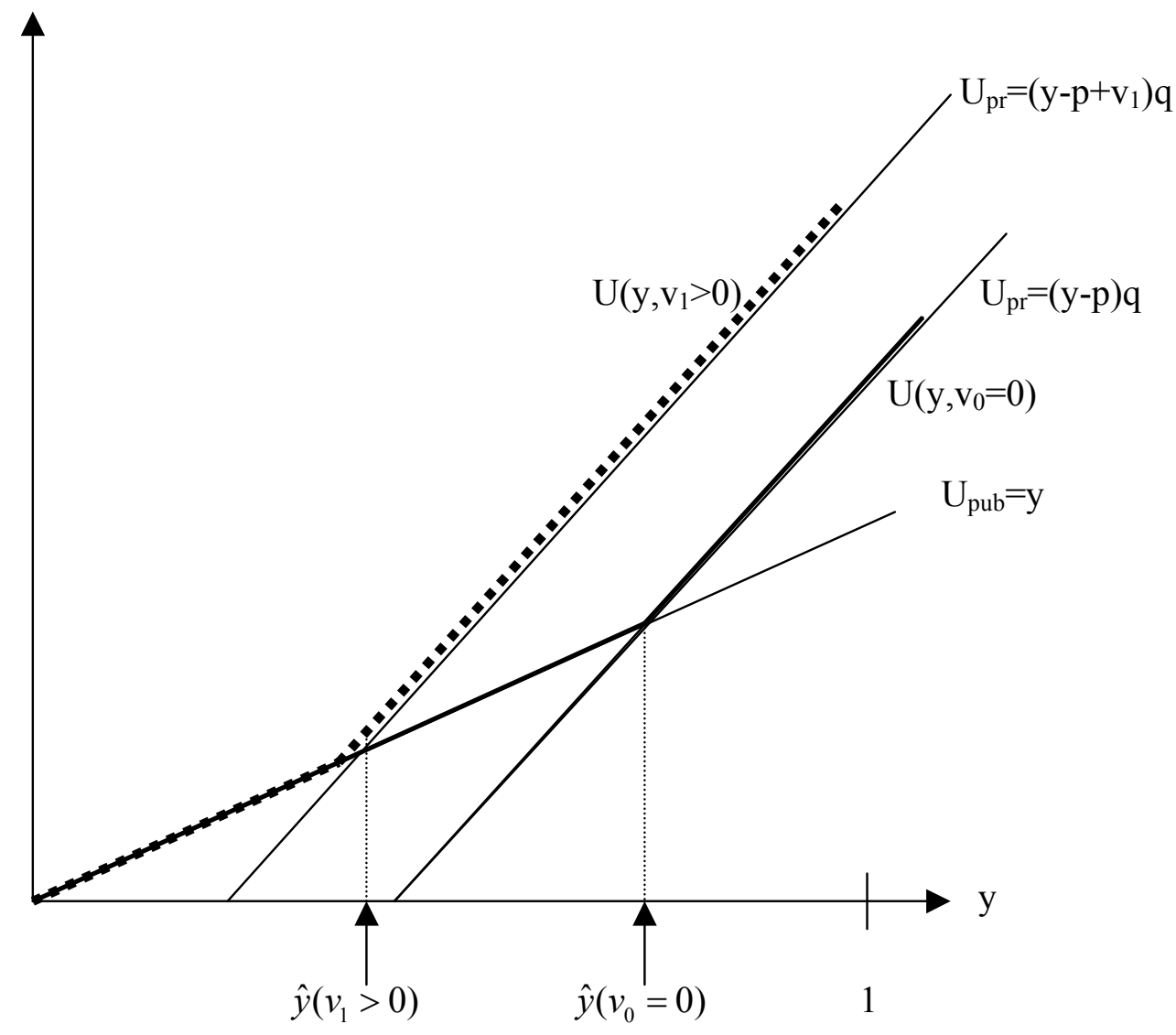

FIGURE 1 


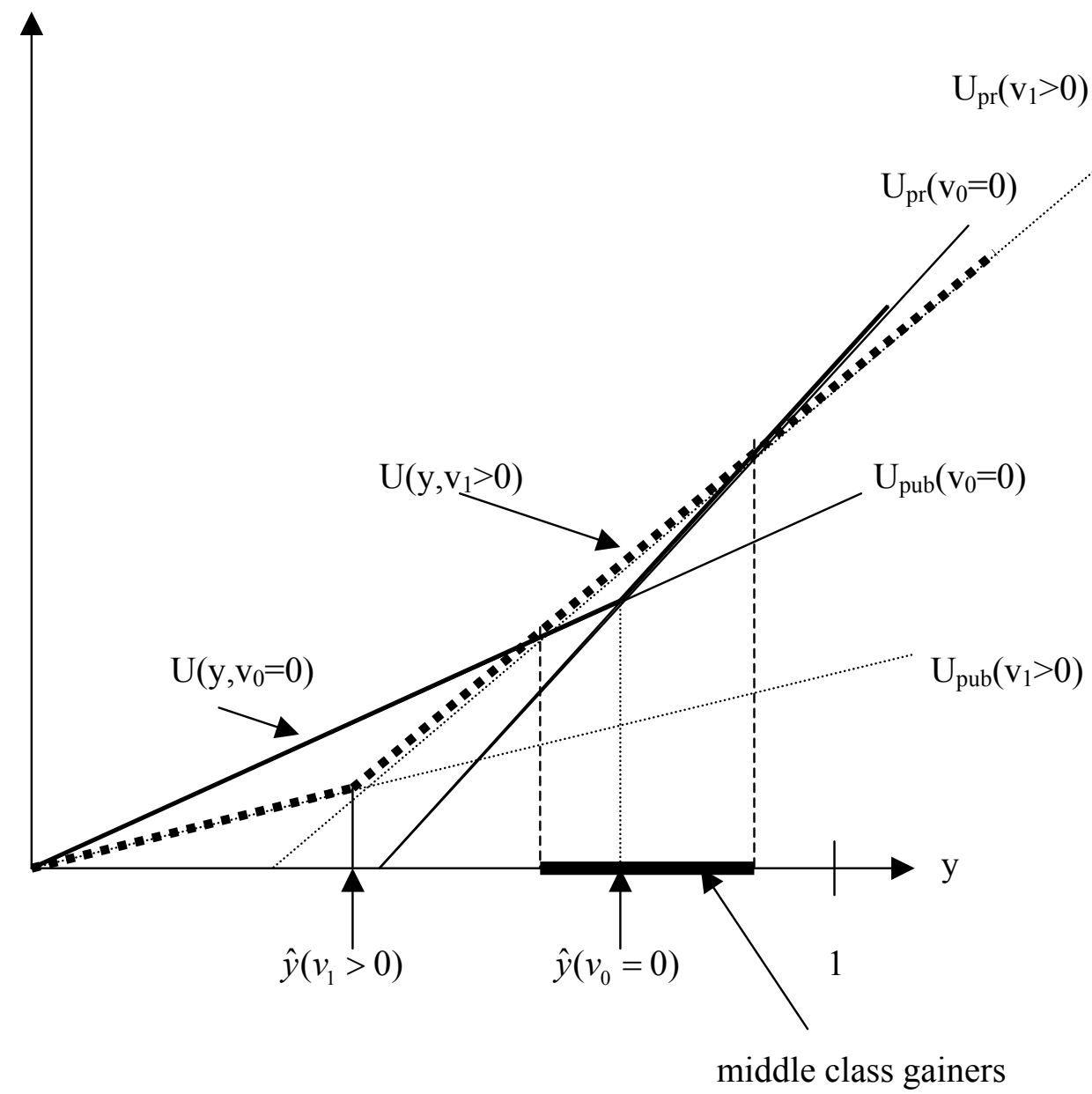

FIGURE 2 